\begin{tabular}{|c|c|c|c|c|c|c|c|c|c|}
\hline $\bar{\pi}$ & $\mathrm{H}$ & I & $\mathrm{R}$ & 7 & 0 & 4 & Operator: Huang Liping & Dispatch: 09.02 .07 & PE: Audrey Khew \\
\hline & Journa & $\mathrm{IN}$ & & Manu & rin & Jo. & Proofreader: Zheng Yeping & No. of Pages: 7 & Copy-editor: Anne Wilson \\
\hline
\end{tabular}

\title{
International perspectives and initiatives
}

Jeannette Murphy, Royal Free and University College Medical School, London, UK

I am delighted to have been asked to develop and co-ordinate this new column which seeks to keep readers abreast of international developments in the fields of health science librarianship and health informatics. This inaugural piece considers the relevance of these themes to our readership, highlights examples of current international initiatives and sets a direction for the column.

\section{The rationale for a column with an international dimension}

'An age-old idea of philosophers is that knowledge of the self is gained through knowledge of others. What is true for the individual is even more so for societies. There is no nation without other nations.... Observers who cultivate a distance between themselves and the society in which they live will find new perspectives opening.'1

The public sector places great emphasis on learning from best practice. We are encouraged to form communities of practice and to share knowledge, skills and experience. ${ }^{2-4}$ In general, this exchange of ideas happens at local, regional and national levels. However, in the 21 st century we need also to be aware of trends in other countries. As the mass media constantly remind us, we live in a time of globalization, with rapid transfer of knowledge, ideas, people and technologies. The way other countries manage health care, the way they train their health-care staff, the way they manage information, and the way they use or plan to use information and communication technologies - all these developments are of interest to the world of health information professionals. 5 To achieve an international perspective we need to overcome ethnocentrism and the tendency to think that national differences preclude generalizing from other societies.
Common challenges in health care

Although there are many differences between countries and regions in the way health care is funded and delivered, there are also common challenges. ${ }^{6-9}$ As Don Detmer (2003) points out, the development of a national health information structure has global dimensions. 10 p. 4 There is significant potential to learn from countries that may be ahead in planning and development. There is also the fact that data content and format standards must cross national boundaries. Furthermore, medical knowledge is one of the most important resources that the developed world provides to other nations.

One way of characterizing the global challenge facing health-care professionals is the need to adopt health-care systems designed for the 19th and 20th century to the needs of 21 st century. Some commentators suggest this redesign requires a transition from Industrial Age Medicine to Information Age Healthcare. 11 The link between information and health-care quality is a recurrent theme in the literature:

'... a major bottleneck to improving health service delivery is a lack of access to quality health information. We need leadership within academic medicine to promote access and use of information communication technologies addressing global health issues.' 12

'Many avoidable shortcomings in the health sector that result in poor quality are due to inaccessible data, information, and knowledge.'10

In their article setting out a research agenda for health informatics, Kaplan et al. (2001) describe two major macro-level trends which are converging to change how health-care services are forming trans-nationally. ${ }^{13}$ 
'The first of these major trends is the split between "haves" and "have nots", not only within a country but between countries as well. This leads to the second trend - the growing demand for health care and related services that match Western standards.' 13

They argue that these trends are leading informatics, as an information-intensive industry, to become a major pillar of health care. But, although there are similar drivers, different countries have different needs. From this they conclude that: 'Although we can ship technology internationally, technology transfer is not successful unless we take into account differences in process and people in different places.'

\section{Scope and purpose of the column}

The aim of the column is to help readers keep abreast of what is happening in other countries as regards policies, practices, politics, and the economics of health information management. It will provide a platform for experts around the world. This column will review developments relating to systems and methods of collecting, organizing and sharing health information in different regions and countries. The column will consider issues relating both to the management of patient information and the biomedical knowledge base of health.

\section{Evidence of an international perspective on health information}

There are signs that health information professionals in the 21 st century are increasingly aware that developments and initiatives in other countries can help them to make sense of the challenges they face in their own environments. Various experts have stressed the need for a global perspective. ${ }^{14-17}$ Madge and Plutchak (2005) have already reviewed globalization in the area of health librarianship. ${ }^{18}$ Hence, this issue will focus mainly on health informatics. It is beyond the scope of this inaugural article to provide a systematic analysis of the ways in which health informatics is developing a comparative perspective. The intention at this stage is to point to evidence which suggests that health informatics increasingly recognizes the value of cross country comparisons and co-operation. Four main types of evidence will be cited: research reports and reviews which adopt a comparative approach; international activities by professional associations and standards organizations; activities within the EU; and indications of the globalization of education and training.

Examples of health informatics research with a comparative dimension

Research in health informatics, as in all scientific disciplines, involves international co-operation and is shared via peer-reviewed journals. But we are beginning to see a more self-conscious effort by scholars to compare the ways in which health informatics is being incorporated into health care in different countries. Examples of recent research which compares and contrasts how technology is being used in different countries are summarized here.

Denis Protti's world view reports. Professor Denis Protti was commissioned by the NHS to write a series of World View Reports concerning IT in health care for the NHS. These reports incorporate research evidence from a variety of countries. ${ }^{19}$

Cross country comparisons of primary care computing. Protti (2006) has carried out a comparative study investigating how computers are being used in primary care in 10 different countries. ${ }^{20}$ Schoen et al. (2006) have also carried out a survey of how primary care doctors in seven countries are using computers. ${ }^{21}$

Personal health records in four countries - report by AMIA president. The President of the American Medical Informatics Association has just coauthored a research report, Learning from Abroad: Lessons and Questions on Personal Health Records for National Policy. ${ }^{22}$ Detmer and Steed's report reviews the adoption of personal health records in Australia, Canada, England and New Zealand and draws global lessons for national IT programmes. The authors conclude that whilst differences between the US health-care system and 
those in the nations studied preclude wholesale borrowing of ideas and approaches, there are areas of common focus and shared purpose. These include recognition of the need to improve health-care quality and safety, the need for robust information infrastructures, and the importance of designing patient-centric systems. The report identified five areas where US policy makers can learn from the experiences of other countries.

The authors comment on cultural differences between the countries studied and the USA, noting that the USA emphasizes individualism, while the nations studied focus on the collective or social solidarity. The authors suggest that US citizens have a distrust of government and preference for private solutions to social issues, so the private sector has a significant role in the delivery and financing of health care.

Case studies - health informatics in individual regions and countries. There is a growing literature which describes how communication and information technology is being used in various regions and countries. A recent book, for example, looks at the new Accession States to the European Union. ${ }^{23}$ Sarbandhikari (2005) has summarized the state of medical informatics in India; ${ }^{24}$ Lun (2003) has outlined the challenges facing the Asia Pacific. ${ }^{25}$ The European Commission has published a series of 10 case studies showing the economic benefits of eHealth solutions. ${ }^{26}$

International activities by professional associations and standards bodies

Like health science librarianship, health informatics has both national and international associations.

The International Medical Informatics Association (IMIA). IMIA defines its role as that of gatekeeper for medical informatics issues in the international community. The association derived from Technical Committee 4 of the International Federation for Information Processing (IFIP). In 1979 it became a fully independent organization. It has close ties with the World Health Organization (WHO). One of its basic objectives is to advance and nurture international co-operation. The Council consists of representatives from most countries of the world. IMIA organizes a large international conference (MEDINFO) every 3 years. The theme of the 2001 meeting was 'Towards Global Health: The Informatics Route to Knowledge'. ${ }^{27}$ National IMIA members may organize into regional groups. There are four regional groupings: Latin America and the Caribbean (IMIA LAC), Europe (EFMI), Asia/Pacific (APAMI) and Africa (Helina). ${ }^{28}$

IMIA has a Working Group (WG09) devoted to Health Informatics for Development. In the next few years there are plans to focus on 'bridging the knowledge gap' by facilitating and providing support to developing nations. Specific goals include supporting the ongoing development of the African region. The development of a 'Virtual University, is an ongoing initiative of IMIA's Working Group 1 (Health and Medical Informatics Education).

IMIA publishes a Yearbook of Medical Informatics which gives an overview of leading and original research in Health and Medical Informatics from the prior year. The first issue appeared in 1992. Many of the articles summarize international trends and developments in health informatics. ${ }^{29}$

International standards working groups. There are a number of different groups involved in developing international standards for health informaticsboth technical standards and standards relating to terminology, coding and classification. There are four key bodies.

- The International Organization for Standardization (ISO) has a technical committee (TC 215) dealing with standardization in the field of information for health, and Health Information and Communications Technology (ICT). The aims are (i) to achieve compatibility and interoperability between independent systems; (ii) to ensure compatibility of data for comparative statistical purposes; and (iii) to reduce duplication of effort and redundancies. ${ }^{30}$

- CEN/TC 251-This is the European body mandated to develop standards for Health Informatics. ${ }^{31}$

- Health Level Seven (HL7) is one of several American National Standards Institute (ANSI) accredited Standards Developing Organizations operating in the healthcare arena. ${ }^{32} \mathrm{HL} 7$ aims to 
provide a comprehensive framework (and related standards) for the exchange, integration, sharing and retrieval of electronic health information. HL7 is now an international community of healthcare subject matter experts and information scientists collaborating to create standards for the exchange, management and integration of electronic health-care information. The standards, which support clinical practice and the management, delivery, and evaluation of health services, are the most commonly used in the world.

- SNOMED International. With the increasing momentum behind government-promoted moves, both in North America and in Europe, to develop integrated electronic health-care records, it is vital that they are fit for purpose. Critical to the successful implementation of such programmes is the availability of a structured terminology to record the important elements of health care in a systematic way, without being unduly restrictive in the range of terms and language required by the numerous individuals, groups, and organizations who will be expected to use it. The Systematized Nomenclature of Medicine-Clinical Terms (SNOWMED) is a comprehensive clinical terminology formed by the convergence of SNOMED RT ${ }^{\circledR}$ and the UK's Clinical Terms Version 3 (formerly known as the Read Codes). It is used in 38 countries and maps to other international standards. Its goal is to become the global clinical terminology. 33,34

\section{Activities within the European Union (EU)}

The EU is aware of the importance of adapting to the challenges globalization poses to the healthcare sector. Since 1984, there has been ongoing collaborative work in health informatics and a variety of policy actions relating to eHealth have been adopted. ${ }^{35-38}$

- Ensure that primary and secondary health-care providers have health telematics infrastructure in place including regional networks.

- Identify and disseminate best practice in electronic health services in Europe.

- Establish a set of quality criteria for health-related websites.

- Establish health technology and data assessment networks.
- Publish a communication on legal aspects of eHealth.

- Identify a common approach to patient identifying data.

- Support the deployment of health information networks base on fixed and wireless broadband and mobile infrastructures and Grid technologies. The Framework Programmes (FPs) have been the main funding mechanism through which the EU supports research and development activities. 39,40 The co-financing allocated since the early 1990 s has reached $€ 500$ million, with a total budget about twice that amount. The emerging e-Health industry has the potential to be the third largest industry in the health sector with a turnover of $€ 11$ billion. By 2010 it is expected to account for 5\% of the total health budget of the European Union's Member States. FP6, the current programme, comes to end in 2006. FP7 becomes operational on 1 January 2007 and will run for 7 years.

Educational initiatives aimed at an international market

'A crucial element in the training and education of tomorrow's medical informatics specialists is exposure to health-care systems across national borders.' 41 p.?? (2004)

IMIA's Working Group on Education held a conference in Oregon in 2003, the theme of which was 'Teach Globally, Learn Locally'. 42 An IMIAsponsored book, Global Health Informatics Education, was published in 2004.43 A variety of educational initiatives have been launched to develop international partnership and to enable students to study abroad. The International Partnership for Health Informatics Education (IPHIE) dates from 1999 and seeks to maintain, improve and promote medical and health informatics training and education through international collaboration. 44 It was formed by a group of six universities, the University of Amsterdam, the Universities of Heidelberg and Heilbronn, the University of Health Sciences, Medical Informatics and Technology at Innsbruck, the University of Minnesota and the University of Utah. IPHIE sponsors activities such as a student and faculty exchange programme, yearly master classes in 
medical and health informatics for honours students, student workshops at main medical informatics conferences, and a joint European course on strategic information management in hospitals.

With the growing popularity of elearning, many universities are developing online Health Informatics degrees and seek to attract international students. ${ }^{45-47}$ Various groups have collaborated to create online learning materials aimed at students and professionals in developing countries. 48,49

\section{Conclusion}

The purpose of this brief review has been to demonstrate that in the field of health informatics, as in the field of health-care librarianship, there is awareness of the necessity and the benefits of adopting an international perspective. Lack of space has precluded looking at collaborations aimed at helping developing countries identify their health needs and ensuring that any international standards that develop are suitable for them. ${ }^{50-52}$ Likewise, it has not been possible to review eHealth developments co-ordinated by the World Health Organization or to look at how developments in telemedicine are resulting in global partnerships. However, these areas will be explored in future issues.

\section{Looking ahead}

Future issues of this column will be devoted to developments in the management of health information in other countries and regions. Experts from around the world will be invited to share their knowledge and experience. As column editor, I would welcome suggestions as to whom to approach - be they academics, medical librarians, and leaders in the field of health informatics or national policy advisors. I would like at the outset to focus on countries which are less well represented in the mainstream academic literature. Contributors will be asked to outline trends, take stock, point to major achievements, describe national strategies/ policies and reflect on their experiences.

\section{References}

1 Mattei, D. \& Dominique, P. How to Compare Nations: Strategies in Comparative Politics. New Jersey: Chatham
House Publishers, 1984: 5-6. Available from: http://poli.haifa.ac.ul/ levi/whycompare.htm (accessed 15 November 2006).

2 Department of Health, Institute of Innovation and Improvement. Available from: http://www.

healthandsocialcareawards.org/

Page_Show.aspx? Id $=494 \&$ Page $=12$

(accessed 15 November 2006).

3 Specialist Library- Knowledge Management. Available from: http://www.nelh.nhs.uk/knowledge_management/ km2/best_practices_toolkit.asp (accessed 15 November 2006).

4 NHS Faculty of Health Informatics. Available from: http://www.informatics.nhs.uk/cgi-bin/item.cgi?id=1489 (accessed 15 November 2006).

5 Kun, L. G. Telehealth and the global health network in the 21 st century. From homecare to public health informatics. Computer Methods and Programs in Biomedicine 2001, 64, 155-67.

6 Nytrø, Ø. \& Farvaag, A. Healthcare Informatics Towards 2020. Available from: http://www.ime.ntnu.no/infosam2020/ $\mathrm{wg} /$ printerfriendly.php?report=health_informatics (accessed 15 November 2006).

7 Haux, R., Ammenwerth, E., Herzog, W. \& Knaup, P. Health care in the information society. A prognosis for the year 2013. International Journal of Medical Informatics 2003, 66, 3-21.

8 Zelmer, J., Virani, S. \& Alvarez, R. Recent Developments in Health Information: an international perspective. Paper commissioned by the National Committee for Vital and Health Statistics for a Workshop on Developing the 21st Century Vision for Health Statistics, December 1999. 1999. Available from: http://www.ncvhs.hhs.gov/hsvision/ CP-zelmer.pdf (accessed 18 November 2006).

9 Hall, A. \& Graham Walton, G. Information overload within the health-care system: a literature review. Health Information and Libraries Journal 2004, 21, 102-8.

10 Detmer, D. E. Building the national health information infrastructure for personal health, health care services, public health, and research. BMC Medical Informatics and Decision Making 2003. Available from: http://www.biomedcentral.com/1472-6947/3/1 (accessed 10 November 2006).

11 Smith, R. The future of healthcare systems. British Medical Journal 1997, 314, 1495.

12 Sewankambo, N. Academic medicine and global health responsibilities. British Medical Journal 2004, 329, 752.

13 Kaplan, B., Brennan, P. F., Dowling, A. F., Friedman, C. P. \& Peel, V. Towards an informatics research agenda: key people and organisational issues. Journal of the American Medical Informatics Association 2001, 8, 235-41.

14 Haux, R. Individualization, globalization and healthabout sustainable information technologies and the aim of medical informatics. International Journal of Medical Informatics 2006, 75, 795-808. 
15 Grimson, J., Grimson, W. \& Hasselbring, W. The SI challenge in Health Care. Communications of the ACM 2000, 43, 49-55.

16 Haux, R. Health information systems - past, present, future. International Journal of Medical Informatics 2006, $\mathbf{7 5}, 268-81$.

17 Vimarlund, V., Timpka, T. \& Patel, V. L. Information technology and knowledge exchange in health-care organizations. Proceedings of the AMIA Symposium, 1999. Available from: http://www.amia.org/pubs/symposia/ D005803.PDF (accessed 19 November 2006).

18 Madge, B. \& Plutchak, T. S. The increasing globalization of health librarianship: a brief survey of international trends and activities. Health Information and Libraries Journal 2005, 22(Suppl. 1), 20-30.

19 Protti, D. World View Reports. Available from: http://www.connectingforhealth.nhs.uk/worldview (accessed 14 November 2006).

20 Protti, D. An Overview of Global Paths to ExR Journeys. 2006. Available from: http://www.wales.nhs.uk/ihc/documents/ Global\%20Approach \%20-\%20Denis\%20Protti.pdf (accessed 14 November 2006).

21 Schoen, C., Osborn. R., Huynh, P. T., Doty, M., Peugh, J. $\&$ Zapert, K. On the front lines of care: primary care doctors' office systems, experiences, and views in seven countries. Health Affairs 2006, 25. Available from: http://content.healthaffairs.org/cgi/content/abstract/ hlthaff.25.w555 (accessed 15 November 2006).

22 Detmer, D. \& Steen, E. Learning from Abroad: Lessons and Questions on Personal Health Records for National Policy. XXXX: AARP, 2006. Available from: http:// assets.aarp.org/rgcenter/health/2006_10_phr_abroad.pdf (accessed 15 November 2006).

23 Duplaga, M. K., Zielinski, K. \& Ingram, D. (eds) Transformation of Healthcare with Information Technologies, Studies in Health Technology and Informatics Series no 105. Amsterdam: IOS Publications, 2004.

24 Sarbadhikari, S. N. The state of medical informatics in India: a roadmap for optimal organization. Journal of Medical Systems 2005, 29, 125-41.

25 Lun, K. C. Medical Informatics: Challenges for the Asia Pacific. APAMI \& CJKMI-KOSMI Conference 2003. Available from: http://kosmi.snubi.org/APAMI/resource/ plenary3_Lun.pdf (accessed 15 November 2006).

26 Stroetmann, K. A., Jones, T., Dobrev, A. \& Stroetmann, V. N. eHealth is Worth It:-The Economic Benefits of Implementing eHealth Solutions at Ten European Sites. XXXX: European Communities, 2006. Available at: $\mathrm{http} / / /$ europa.eu.int/information_society/newsroom/cf/ document.cfm?action $=$ display\&doc_id $=176$ (accessed 14 November 2006).

27 Stangler, R. S. Conference Report: Towards Global Health: The Informatics Route to Knowledge. Available from: http://www.medscape.com/viewarticle/415046_print (accessed 18 November 2006).

28 IMIA. Available from: http://www.imia.org/ (accessed 14 November 2006).
29 Lorenzi, N. M. E-Health Strategies Worldwide. In: IMIA Yearbook of Medical Informatics. Stuttgart: Schattauer, 2005: 157-65.

30 International Organisation for Standarization (IOS). Available from: http://www.iso.org/iso/en/stdsdevelopment/ tc/tclist/TechnicalCommitteeDetailPage.

TechnicalCommitteeDetail?COMMID $=4720$ (accessed 17 November 200).

31 European Standardization of Health Informatics-CEN/ TC 251. Available from: http://www.centc251.org/ (accessed 14 November 2006).

32 Health Level Seven (HL7). Available from: http://www.hl7.org/ (accessed 14 November 2006) and http://en.wikipedia.org/wiki/HL7 (accessed 14 November 2006).

33 Snomed International. Available from: http:// www.snomed.org/ (accessed 15 November 2006). See also: http://www.openclinical.org/medTermSnomedCT.html.

34 Chalmers, R. J. G. Health Care Terminology for the Electronic Era. Mayo Clinic Proceedings 2006. Available from: http://www.mayoclinicproceedings.com/ pdf $\% 2$ F $8106 \% 2 F 8106 \mathrm{e} 1$ (accessed 15 November 2006).

35 European Union. e-Health - Making Healthcare Better for European Citizens: An Action Plan for a European e-Health Area, COM (2004) 356. 2004. Available from: $\mathrm{http}: / / w w w . e u r o p a . e u . i n t / i n f o r m a t i o n \_s o c i e t y / q u a l i f /$ health/index_eng.htm (accessed 28 October 2006).

36 Commission of the European Communities. COM (2004) 356 final: ' $e$-Health - making healthcare better for European citizens: An action plan for a European e-Health Area'. 2004. Available from: http://europa.eu/eur-lex/en/com/cnc/2004/ com2004_0356en01.pdf (accessed 17 November 2007).

37 Watson, R. EU wants every member to develop a 'roadmap' for ehealth. British Medical Journal 2004, 328, 328.

38 European Union. Harnessing ICTs to Deliver High-Quality Health Care for All. Available from: http://europa.eu.int/ information_society/activities/health/policy_action_plan/ index_en.htm (accessed 14 November 2006).

39 European Union. 6th Framework Programme 2002-2006. Available from: http://ec.europa.eu/research/fp6/ index_en.cfm? $\mathrm{p}=0$ (accessed 15 November 2007).

40 European Union. 7th Framework Programme. Available from: http://cordis.europa.eu/fp7/ (accessed 15 November 2006).

41 Jaspers, M. W., Ammenwerth, E., ter Burg, W. J., Kaiser, F. \& Haux, R. An international course on strategic information management for medical informatics students: international perspectives and evaluation. International Journal of Medical Informatics 2004, 73, 807-15.

42 IMG1-IMIA. Teach globally, learn locally: innovations in health and biomedical informatics education in the 21st century. Proceedings of the IMIA Working Group Conference. April 23-25, 2003. Published as a CD.

43 Hovenga, E. J. S. \& Mantas, J. (eds) Global Health Informatics Education. Amsterdam: IOS Press. IMIA sponsored reader. 
44 The International Partnership for Health Informatics Education - IPHIE (IÖE). Available from: http:// www.iphie.org/ (accessed on 14 November 2006).

45 Oregon Health Science University, Department of Medical Informatics \& Clinical Epidemiology. MS in Medical Informatics by Distance Learning. Available from: http://www.ohsu.edu/ohsuedu/academic/ som/dmice/academics/ms-biomedical.cfm (accessed 14 November 2006).

46 Royal College of Surgeons of Edinburgh and University of Bath. Distance Learning Masters in Health Informatics. Available from: http://www.healthcare-informatics.info/ (accessed 14 November 2006).

47 Health Informatics Life Long Learning. The Health Informatics Society of Australia, in association with the Central Queensland University (CQU) and other partners is planning this new initiative in Health Informatics education. Available from: http://www.hill.org.au/ (accessed 14 November 2006).
48 XXXX. Supercourse. Available from: http://www.pitt.edu/ $\sim$ super1/ (accessed 13 November 2006).

49 e-Health and Learning. Health Informatics Training Courses for Practitioners. Available from: http:// www.ehealth.bham.ac.uk/ehl-hic/index.htm (accessed 17 November 2006).

50 Treseder, P. Health informatics' founding chair looks back at achievements. ISO Bulletin November 2002. Available from: http://www.iso.org/iso/en/commcentre/isobulletin/ articles/2002/pdf/tc21502-11.pdf (accessed 15 November 2006).

51 McLellan, F. Information technology can benefit developing countries. Lancet 2001, 358, 308.

52 Stephens, G. \& Woods, G. An initial investigation into the Role of Health Informatics in the context of Global Health. Proceedings of the 18th IEEE Symposium on Computer-Based Medical Systems (CBMS'05) 2005. Available from: http:// ieeexplore.ieee.org/xpls/abs_all.jsp?arnumber $=1467693$ (accessed 15 November 2006). 


\section{Author Query Form}

\section{Journal: Health Information and Libraries Journal}

\section{Article: hir_704.fm}

Dear Author,

During the copy-editing of your paper, the following queries arose. Please respond to these by marking up your proofs with the necessary changes/additions. Please write your answers on the query sheet if there is insufficient space on the page proofs. Please write clearly and follow the conventions shown on the attached corrections sheet. If returning the proof by fax do not write too close to the paper's edge. Please remember that illegible mark-ups may delay publication.

Many thanks for your assistance.

\begin{tabular}{|c|c|c|}
\hline No. & Query & Remarks \\
\hline 1 & $\begin{array}{l}\text { Royal Free and University College Medical School, London, } \\
\text { UK is this the correct address? }\end{array}$ & \\
\hline 2 & Please confirm if this article needs a summary and keywords. & \\
\hline 3 & $\begin{array}{l}\text { ??? please indicate which page number should be inserted } \\
\text { here }\end{array}$ & \\
\hline 4 & $\begin{array}{l}\text { AARP is this the name of the publisher? Also, please give } \\
\text { location of publisher }\end{array}$ & \\
\hline 5 & please give location for publisher & \\
\hline 6 & $\begin{array}{l}\text { European Union this has been suggested as an author group. } \\
\text { OK? }\end{array}$ & \\
\hline 7 & European Union OK for author group? & \\
\hline 8 & $\begin{array}{l}\mathbf{X X X X} \text { please give the name of an organization or an author } \\
\text { group for this }\end{array}$ & \\
\hline
\end{tabular}




\section{Please correct and return this set}

Please use the proof correction marks shown below for all alterations and corrections. If you wish to return your proof by fax you should ensure that all amendments are written clearly in dark ink and are made well within the page margins.

\begin{tabular}{|c|c|c|}
\hline Instruction to printer & Textual mark & Marginal mark \\
\hline Leave unchanged & ... under matter to remain & ( ) \\
\hline $\begin{array}{l}\text { Insert in text the matter } \\
\text { indicated in the margin }\end{array}$ & $h$ & $\begin{array}{l}\text { New matter followed by } \\
h \text { or } h \otimes\end{array}$ \\
\hline Delete & $\begin{array}{l}\text { I through single character, rule or underline } \\
\text { or }\end{array}$ & $\sigma$ or $\sigma(x)$ \\
\hline $\begin{array}{l}\text { Substitute character or } \\
\text { substitute part of one or } \\
\text { more word(s) }\end{array}$ & I through letter or & $\begin{array}{l}\text { new character / or } \\
\text { new characters / }\end{array}$ \\
\hline Change to italics & — under matter to be changed & $\leftarrow$ \\
\hline Change to capitals & $\equiv$ under matter to be changed & $\equiv$ \\
\hline Change to small capitals & $=$ under matter to be changed & $=$ \\
\hline Change to bold type & $\sim$ under matter to be changed & $\sim$ \\
\hline Change to bold italic & $\bar{\sim}$ under matter to be changed & $\tilde{\omega}$ \\
\hline Change to lower case & Encircle matter to be changed & $\Rightarrow$ \\
\hline Change italic to upright type & (As above) & \\
\hline Change bold to non-bold type & (As above) & \\
\hline Insert 'superior' character & $\begin{array}{l}/ \text { through character or } \\
K \text { where required }\end{array}$ & $\begin{array}{l}y^{\prime} \text { or } y \\
\text { under character } \\
\text { e.g. } y^{2} \text { or } y^{2}\end{array}$ \\
\hline Insert 'inferior' character & (As above) & $\begin{array}{l}\lambda \\
\text { over character } \\
\text { e.g. } \hat{\Sigma}\end{array}$ \\
\hline Insert full stop & (As above) & $\odot$ \\
\hline Insert comma & (As above) & , \\
\hline Insert single quotation marks & (As above) & $\begin{array}{l}\dot{y} \text { or } \dot{x} \text { and/or } \\
\dot{y} \text { or } \dot{y}\end{array}$ \\
\hline Insert double quotation marks & (As above) & $\begin{array}{l}\ddot{y} \text { or } \ddot{x} \text { and/or } \\
\ddot{y} \text { or } \ddot{x}\end{array}$ \\
\hline Insert hyphen & (As above) & 1 \\
\hline Start new paragraph & 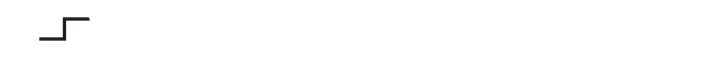 & 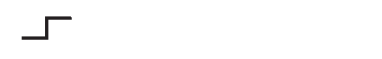 \\
\hline No new paragraph & $\infty$ & $\omega$ \\
\hline Transpose & $\sqcup$ & $\sqcup$ \\
\hline Close up & linking $\bigcirc$ characters & \\
\hline $\begin{array}{l}\text { Insert or substitute space } \\
\text { between characters or words }\end{array}$ & $\begin{array}{l}\text { I through character or } \\
K \text { where required }\end{array}$ & \\
\hline $\begin{array}{l}\text { Reduce space between } \\
\text { characters or words }\end{array}$ & $\begin{array}{l}\text { between characters or } \\
\text { words affected }\end{array}$ & $\uparrow$ \\
\hline
\end{tabular}

